\title{
稻熱病菌の炭水化物分解醉素の分泌に及ぼす Cephalothecin の影響に就いて*
}

吉 井䁈

YosHI, H.: On the influence of cephalothecin upon the secretion of some carbohydrases by the blast fungus.

\section{1. 緒霉}

Cephalothecium 菌の生迹する抗微性物筫Cephalo-

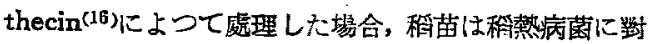

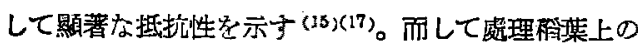
水滴に於ける秷熱病菌胞子の發芽行動の製肘, 供試灌

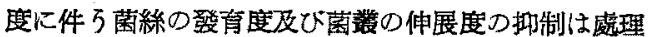

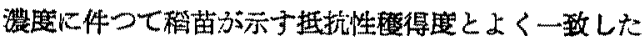
傾向を表す事が粼られている(17)(18)。從つて此等の事

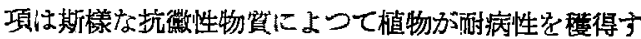
るに至る機構の一部を示すと考えている。然し今间は

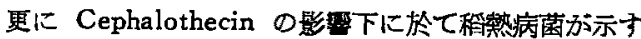

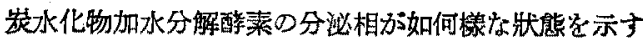

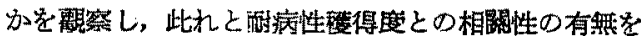
確め以て其機構の解明の一環とする目的を以て本葢臹 を容施した。

䄸熱病菌の榮意生理に關する研究に當つては，Biotin の添加なくしては完全を期しえない事は既に數及

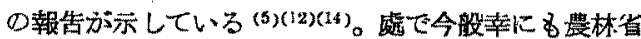

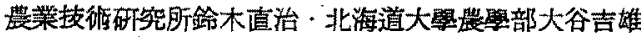
兩氏の御好意により Biotin を入手する事が出來，昭 和 26 年度䆩施 ${ }^{(19)}$ した本零驗法炤和 27 年 Biotin 加用 下に再檢討子る機會を持台得た。本報告は紙數の鬥保 上 Sucrase, Maltase, Amylase 及び Cellulase 等 4

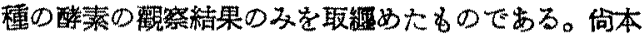

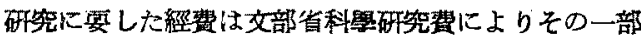

* Cephalothecium 菌によろ農作物の人罵免没法 に開す万研究 第 10 報, 松山磊科大學植物病 理學研究室亲程 第 22 號。

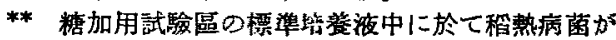

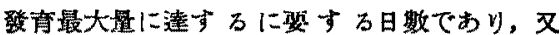

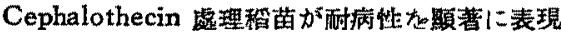
する限界日数である。

*** 栃內・中野兩氏が示した榴熱病菌發青最適浱度 であろ。以下他糖も同樣に各々その至適濃度た 表はす。

**** Fehling 氏溶液え塄元するアルデハィドその他

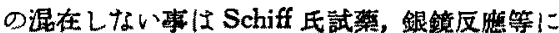
よv磪韶しえだ。
が支辩された。部して感謝の意を表する。又铪木直治

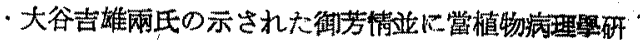
究室各員の觀察に當つて示した積極的な接助に對し梁 謝の意を表する。

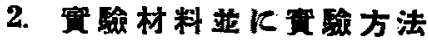

供試した Cephalothecin は本研究第3 報(16)飞基い て作製し，此达培地儿て $5,10,20,40,80,160$ 倍に稀櫂

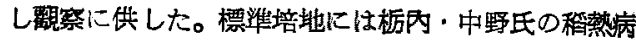
菌用合成培養液(13)を探用し，此仁 Biotin は $1 \mathrm{cc}$ 當 15 〜 $20 \mathrm{~m} 7$, ビタミン $\mathrm{B}_{1}$ (武田㔨品製) は $1 \mathrm{cc}$ 當 15 $20 \tau$ を添加し， $\mathrm{pH}$ は 7.0 に铜節した。培盖に虽つ

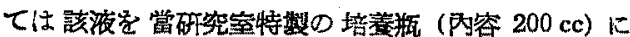
$50 \mathrm{cc}$ 宛分注し, $165^{\circ} \mathrm{C}$ で 15 分間, 3 回蒸策殺菌し た。供試菌は P-3 (京大保存菌) を用い, $25^{\circ} \mathrm{C}$ て 10 日間**培養した。

試簽區には炭水化物加用區と 對照として無加用區 (Cephalothecin 單用通) 表設け，各區には稻熱病菌 を接種したるのと無接種のるのを準碏し，所定の日數

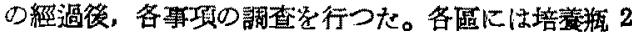
個宛を當て測定值はその平均によつた。供試炭水化物

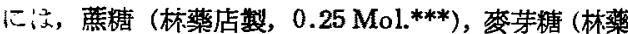
店製， $0.25 \mathrm{Mol}$.)，可客性澱数（片山化學製，0.25 Mol.)，

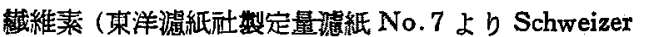

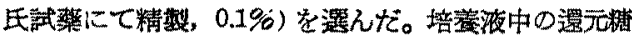
量汢 Micro-Bertrand**** 法によつた。全糖の蕉䌅。

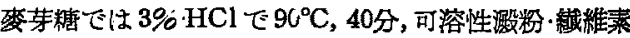
では $25 \%$ (比重 1.125) HCl を以て $100^{\circ} \mathrm{C}, 90$ 分, 夫 及加水分解し，アルカリ中和後，還元糖量を求め此冰 より換算した。而して全啸量より還元糖量を除去した るのを以て非還元栯量を算出した。菌絲量㤬注意して

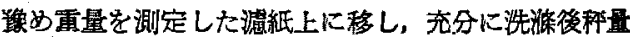
瓶中で乾燥後称量し滤紙重量を美引いて求めた。

䏌 Cephalothecin の影整下潑育する稳熱病藏分 分必する炭水化物分解醅素量を比較检尌する便宣上， Cephalothecin に宸水化物落添加する事によつて，そ

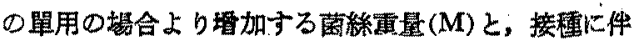


つて消费される非還元䌅量と Cephalothecin 單用の 際に㳦少子る非违元糖量との差 (S) とを求め, 此より S/Mを算出した。

\section{3. 窗噞結果}

a. Sucrase 分䎵についての贯驗：本筫驗は 3 度反 罢家施したが，その結果の一例を示すと第 1 表，第 1 第 1 表 Sucrase 分泌試瞼結果

\begin{tabular}{|c|c|c|c|c|c|c|c|c|c|}
\hline \multirow{2}{*}{$\begin{array}{l}\text { 糖 } \\
\text { D } \\
\text { 種 } \\
\text { 類 }\end{array}$} & \multirow{2}{*}{$\begin{array}{l}\text { 濃 } \\
\text { 度 } \\
\text { 倍 } \\
\end{array}$} & \multirow{2}{*}{$\begin{array}{l}\text { 菌 } \\
\text { 采 } \\
\text { 重 } \\
\text { mg }\end{array}$} & fin & 接 & 種 & \multicolumn{2}{|l|}{ 接 } & & \multirow{2}{*}{$\begin{array}{l}\text { 減 } \\
\text { 糖 } \\
\text { 罿 }\end{array}$} \\
\hline & & & 全糖 & 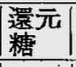 & $\begin{array}{l}\text { 非罟 } \\
\text { 元糖 }\end{array}$ & 全糖 & $\begin{array}{l}\text { 罡元 } \\
\text { 粕 }\end{array}$ & 韭還 & \\
\hline & 5 & 2.1 & & 142.2 & 1661.2 & & 188.3 & 04.7 & 56. \\
\hline & 10 & 3.6 & 53.6 & 136.6 & 1517.0 & 165 & 227.9 & 1425.7 & 91.3 \\
\hline & 20 & 6.8 & 1576.4 & 130.0 & 1446.4 & 15 & 317.4 & 1258.1 & 188 \\
\hline & 40 & 27.8 & 58.5 & 127.1 & 1431.4 & 1555.7 & 61 & 939.8 & 49 \\
\hline & 80 & 35. & 1541.6 & 125.3 & 1416.3 & 1463. & 668.6 & 794.8 & 621 \\
\hline & 160 & 36.8 & 1574.5 & 112.1 & 1462.4 & 1465.3 & 679.0 & 786.3 & 676 \\
\hline & & & & & 1391.9 & & 791 & 657.3 & \\
\hline & 5 & & 96.5 & 39 & 356 & & 65.9 & 286.3 & .6 \\
\hline & 10 & & 226.0 & 31.1 & 194 & 21 & 97 & 115.8 & \\
\hline & 20 & 3. & 127.1 & 27.3 & 99.8 & 125 & 91.3 & 32.1 & \\
\hline & 40 & 6.0 & 81.9 & 24.5 & 57.4 & 59.3 & 42.4 & 16.9 & 40.5 \\
\hline & 80 & 7.1 & 55.6 & 24.5 & 31.1 & 37.7 & 24.5 & 13.2 & 17.9 \\
\hline & 160 & 7. & 47.1 & 23.5 & 23.6 & 35.8 & 21.7 & 14.1 & 9.5 \\
\hline & 標準 & & 34.8 & 21.7 & 13.1 & & 22.7 & 13.1 & 0.0 \\
\hline
\end{tabular}

第 2 表 Maltase 分泌試驗結果

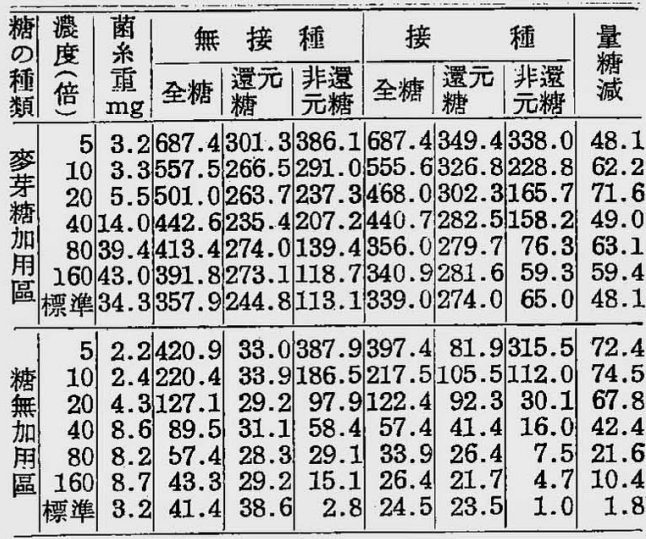

$\mathrm{M}, \mathrm{S}$ 及び $\mathrm{S} / \mathrm{M}$ 值は第 5 表に觀られる。これによるそ

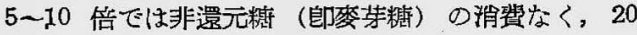
倍に最も著しい消失が認められる。40１60 倍及び㯲 準液では相互間には消費量に餘り羑買はないが, 20 倍 に比すると劣つてるる事が觀られる。

c. Amylase 分泌についての算噞：3 包觀察中の一

詰：糖量は亞酸化銅重量九 mg 單 位で示す。減糖量は接種によ つて消失される非還元糖量え 意味す。以下各表同楾。

圖 (a)に觀られる羊りである。又 Cephalothecin 單用區 (第 1 圖(e)) と比較した菌絲の堙加重量(M) と

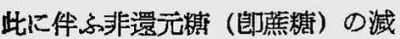
少量 (S) 並に S/M の值は第 5 表 に示す。れによると添加された 堭溏の消費は， 5 倍ては全く認め られず, 10 倍以上の稀釋度に於い て觀祭され，菌絲の墂加につれそ の消費量は，濃成が薄くなるに從 つて次第增加して行く。然しこ れを䒩絲増加量 $1 \mathrm{mg}$ 當りの蔴糖 洞費量郎 S/M で觀ると，第5 表 に示される樣に，20 倍區に於いて

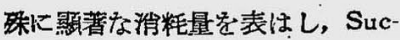
rase の分泌が特に多い事がわか bo

b. Maltase 分泌次ての筫

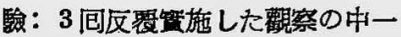
例安示了と，第2表，第1圆 (b) に䤃られる通りである。又，此の

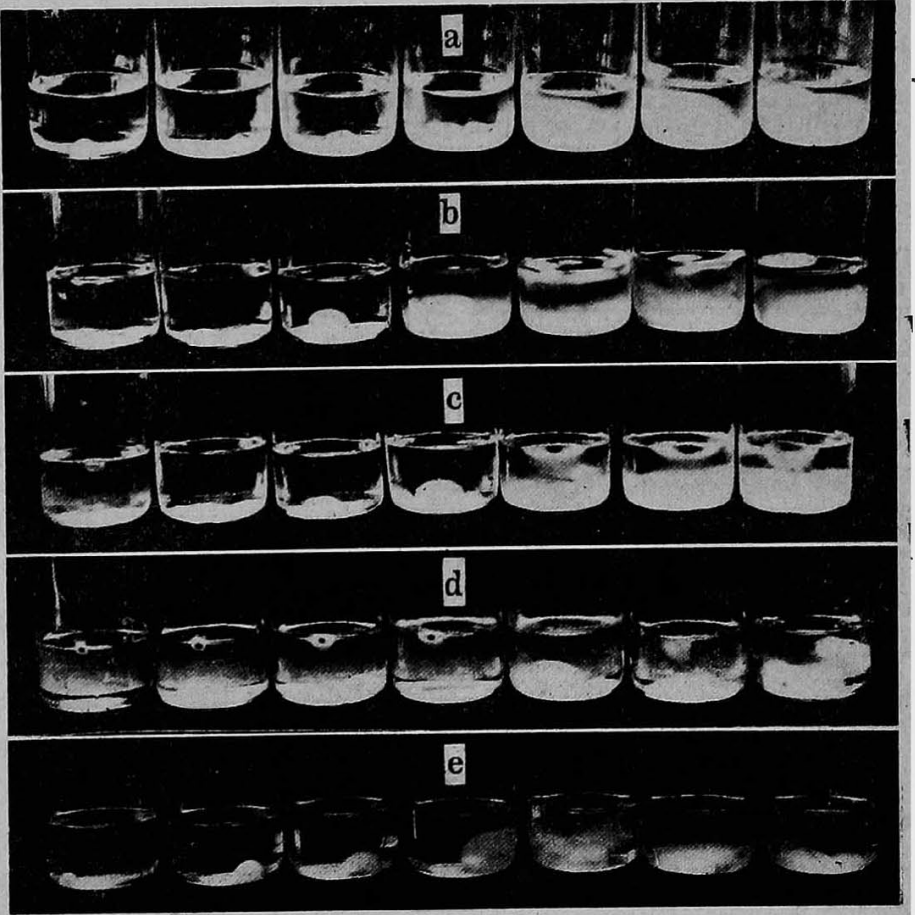

第 1 哟 各種炭水化物によ乃榣熱病菌の發育狀態 左より $5,10,20,40,80,160$ 倍液及び標华液

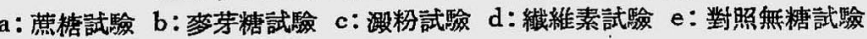


例定示寸と第 3 表，第1圖（c）の通りである。又此の $\mathrm{M}, \mathrm{S}$ 及ひ S/M 值は第 5 表に示してある。Amylase の 分泌相伀前 2 者之稍異なり，分泌量の最高默性 40 倍

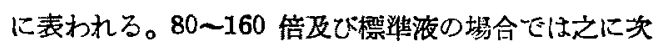
いで分泌は稍少るが，20 倍では更に少くなり，5〜10 倍では全くその分泌は認め蹎くなる。 第 3 表 Amylase 分泌試驗結果

\begin{tabular}{|c|c|c|c|c|c|c|c|c|}
\hline $\begin{array}{c}\text { 糖 } \\
\text { क }\end{array}$ & 䍘 & 無 & 接 & 㮒 & 接 & & 種 & \\
\hline 種套 & $\frac{\text { 重 }}{\mathrm{mg}}$ & 全糖 & $\begin{array}{l}\text { 㵋元 } \\
\text { 糖 }\end{array}$ & $\begin{array}{l}\text { 韭滖 } \\
\text { 元糖 }\end{array}$ & 全糖 & $\begin{array}{l}\text { 還元 } \\
\text { 糖 }\end{array}$ & 韭瀷 & 量 \\
\hline
\end{tabular}

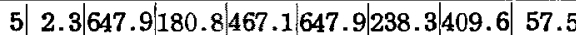
溜 $\quad 10 \quad 2.3497 .2182 .7314 .5484 .0242 .0242 .0 \quad 72.5$

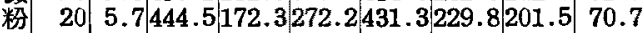
加 $4010.8395 .5 \mid 179.9215 .6356 .0206 .2149 .8$ 65.8 用 8016.8389 .9175 .2214 .7323 .9194 .0129 .984 .8 凅 16021.0380 .5166 .7213 .8307 .0195 .9111 .1102 .7

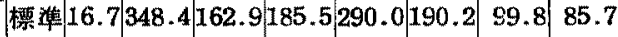

糖無加用區は第 2 表㽣。

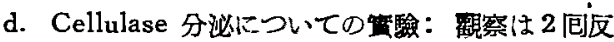
㠅したが，その一例を繁げると第 4 表，第 1 圖 (d) に 觀る通りである。文此の埸合の $\mathrm{M}, \mathrm{S}$ 及び S/M 值住

第 5 表にて求められる。本酵素は供試淔度の 5 160

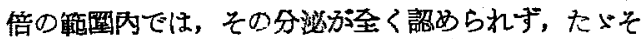

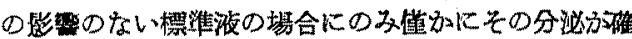
認しえられる。

第 4 表 Cellulase 分沙試驗結果

\begin{tabular}{|c|c|c|c|c|c|c|c|c|}
\hline \multirow{2}{*}{ 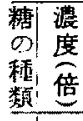 } & \multirow{2}{*}{\begin{tabular}{|c|} 
菌 \\
采 \\
熏 \\
mg \\
\end{tabular}} & \multicolumn{3}{|c|}{ 無 接 程 } & \multicolumn{2}{|l|}{ 接 } & 種 & \multirow{2}{*}{$\begin{array}{l}\text { 減 } \\
\text { 糖 } \\
\text { 量 }\end{array}$} \\
\hline & & 全糖 & \begin{tabular}{|l} 
還元 \\
糖
\end{tabular} & 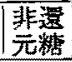 & 全糖 & \begin{tabular}{|l|} 
還元 \\
糖 \\
\end{tabular} & $\left|\begin{array}{|l|l}\text { 韭僄 } \\
\text { 元糖 }\end{array}\right|$ & \\
\hline 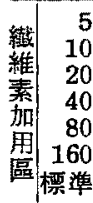 & $\begin{array}{l}1.0 \\
1.2 \\
3.4 \\
4.2 \\
5.1 \\
5.5 \\
4.8\end{array}$ & \begin{tabular}{|r}
525.5 \\
320.2 \\
180.8 \\
122.4 \\
92.3 \\
67.8 \\
45.2
\end{tabular} & \begin{tabular}{|r}
35.8 \\
26.4 \\
19.8 \\
19.8 \\
16.0 \\
8.5 \\
11.3
\end{tabular} & $\begin{array}{l}161.0 \\
102.6 \\
76.3 \\
59.3 \\
33.9\end{array}$ & $\begin{array}{l}67.8 \\
37.7\end{array}$ & \begin{tabular}{|r|}
50.9 \\
47.1 \\
43.3 \\
42.4 \\
33.0 \\
19.8 \\
9.4
\end{tabular} & \begin{tabular}{|}
113.0 \\
76.3 \\
57.4 \\
48.0 \\
28.3
\end{tabular} & $\begin{array}{r}48 . \\
26 . \\
18 . \\
11 . \\
5 .\end{array}$ \\
\hline $\begin{array}{r}5 \\
10 \\
20 \\
40 \\
80 \\
160 \\
160 \\
\text { 標準 }\end{array}$ & $\begin{array}{l}1.2 \\
2.2 \\
2.5 \\
2.8 \\
5.0 \\
6.4 \\
2.7\end{array}$ & $\begin{array}{l}79 . \\
50 . \\
39 . \\
33 .\end{array}$ & $\begin{array}{l}17 \\
17 \\
11 \\
10\end{array}$ & $\begin{array}{l}61.2 \\
33.9 \\
28.3 \\
23.5\end{array}$ & $\begin{array}{l}35 . \\
31 .\end{array}$ & \begin{tabular}{|r|}
59.3 \\
65.0 \\
42.4 \\
37.7 \\
37.7 \\
19.8 \\
8.5
\end{tabular} & $\begin{array}{l}76.3 \\
18.8 \\
15.0 \\
16.0 \\
22.6\end{array}$ & $\begin{array}{r}12.3 \\
0.9\end{array}$ \\
\hline
\end{tabular}

第 5 表 各蟀素についての $M, S$ 及び $S / M$ 湘定結果

\begin{tabular}{|c|c|c|c|c|c|c|c|c|c|c|c|c|}
\hline \multirow{2}{*}{$\begin{array}{l}\text { 濃 } \\
\text { 度 } \\
\text { 倍 } \\
\end{array}$} & \multicolumn{3}{|c|}{ Sucrose } & \multicolumn{3}{|c|}{ Maltose } & \multicolumn{3}{|c|}{ Soluble starch } & \multicolumn{3}{|c|}{ Cellulose } \\
\hline & $\mathbf{M}$ & $S$ & $\mathbf{S} / \mathbf{M}$ & $\mathbf{M}$ & $\mathbf{S}$ & $\mathrm{S} / \mathrm{M}$ & $\mathbf{M}$ & $\mathbf{S}$ & S/M & $\mathbf{M}$ & $\mathbf{S}$ & $\mathbf{S} / \mathrm{M}$ \\
\hline 5 & +0.8 & 0.0 & 0.0 & +1.0 & 0.0 & 0.0 & +0.1 & 0.0 & 0.0 & -0.2 & 0.0 & 0.0 \\
\hline 10 & +1.1 & 12.2 & 11.1 & +0.9 & 0.0 & 0.0 & -0.1 & 0.0 & 0.0 & -1.0 & 0.0 & 0.0 \\
\hline 20 & +3.4 & 120.6 & 35.5 & +1.2 & 3.8 & 3.2 & +1.4 & 2.9 & 2.1 & +0.9 & 0.0 & 0.0 \\
\hline 40 & +21.8 & 451.1 & 20.7 & +5.4 & 6.6 & 1.2 & $\begin{array}{r}2.2 \\
\end{array}$ & 23.4 & 10.7 & +1.4 & 0.0 & 0.0 \\
\hline 80 & +28.5 & 603.6 & 21.2 & +31.2 & 41.5 & $1 . \overline{3}$ & +8.6 & 63.2 & 7.4 & +0.1 & 0.0 & 0.0 \\
\hline 160 & +29.3 & 666.6 & 22.8 & +35.3 & 49.0 & 1.4 & +12.3 & 92.3 & 7.5 & -0.9 & 0.0 & 0.0 \\
\hline 標準 & $\begin{array}{r}+32.7 \\
\end{array}$ & 734.6 & 22.5 & +31.1 & 46.3 & 1.5 & +13.5 & 83.9 & 6.2 & +2.1 & 4.7 & 2.2 \\
\hline
\end{tabular}

註 菌系重は mg, 糖量は亞酸化銅重量九 $\mathrm{mg}$ 單位で示す。

\section{4. 考察}

楾熱病菌加分泌する炭水化物加水分解醉素之しては

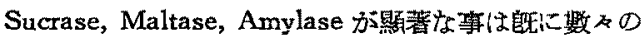
報告(8)(10)(11)(13)により明かである。本篮簽に於ても此 等の酵素注, Cephalothecin の 20 倍以上の稀䖽度に 於て，明かに多量の分泌壳確認しえた。然しその分必 相は醇素の種類により夫々特異性を示すのは留意すぺ 灵事で击る。依つてその分泌相を觀るために，前項て

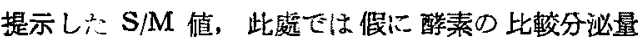
(relative secretion value) と呼ぶが，とれに基いて 醉素の分泌相灾觀ると次の樣になる。

第1は Sucrase 汇觀られる分必相である。これは

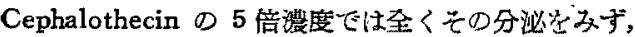
10 倍で值加之をを認め万る。20〜160 倍区び標準液
では多量の分泌が唯認される。殊に20 偣では他の濃 度に比し分泌分特に赫著でる。此分泌琵は Sucrase

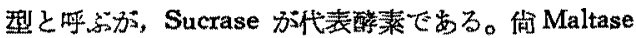
は分速务5〜10倍では全く䛬められない。所でCepha-

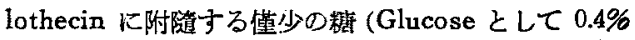
以下) は程熱病菌の Maltase 分泌儿は殆んど影䇾の ない事 (来發表) から，10 倍でその分泌のない事は，

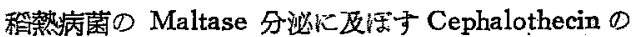
影䍌は Sucrase の埸合之稍翼なると考方られる。然

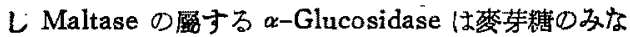

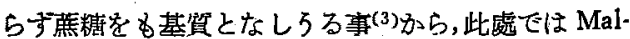
tase は Sucrase 型に犀すると考えて居る。一

第2 2 Amylase に䚈られる分班型である。これで は䣼素の分泌は 5〜10 倍で全く認め得ず,20倍より 初めて認められ，40 倍に於て最大值を示す。80 -160 


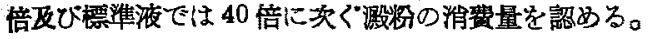
所で絲狀菌の分泌する Amylase はその基管の有無に

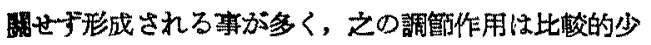

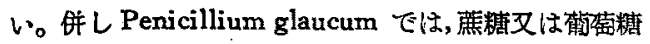
が全液の 1.5\% 超えると Amylase の形成が广い。 Aspexgillus niger では䈍糖濃度 $3 \%$ で Amylase $の$ 形成が阻害せられる。及 Aspergillus oryzae では籍

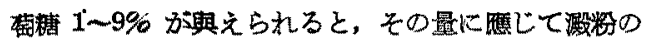
榙化力が減ずる事が知られている(9)。從つて Cephalothecin に附隨する精を菊萄糖にて相賞量 $(0.4 \%$ 以 下) 添加し稳熱病菌の Amylase 分必老检したが，こ

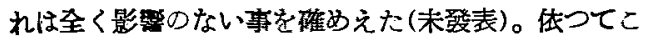

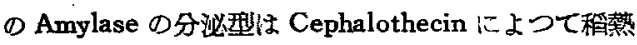

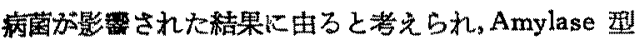
と呼ぶ事にする。Amylaseはこれに的する唯一の䣼等 でる。

第3は Cellulase に觀る型でする。これは供陚濃度 の範圈たは分泌が全く認められず，その影瑟つない場

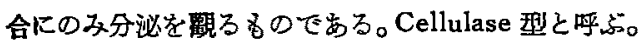
とれた属するすのしては他に Emulsin, Inulinase, Lactase, Mannase, Pectinase, Xylanase が觀られて Љる(19)(21))。

㔯 Cephalothecin 方菌の分泌酸素に賦活劑 (Activater) 又は阻害齊 (Inhibitor) として作用寸る事若 周せられたので各䤃素を常法(1)(4)に翼つて純粹に分離 したるのに就き，その活力に及佂す Cephalothecin

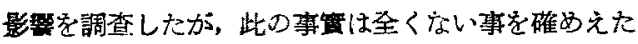
(末登表)。

般て酻素つ比較分泌量 ( $\mathrm{S} / \mathrm{M}$ 值) は, Cephalothecin に炭素源を添加する事によつて，その單用の場合より

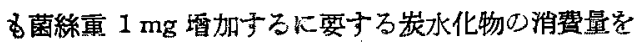
示している。從つて此の逆数值 (唭 M/S 值), 所㒛

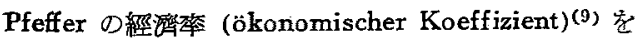
求めれは炭水化物 $1 \mathrm{mg} \emptyset$ 消費によつて墂加する菌糸

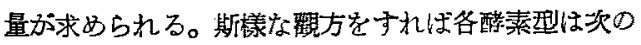

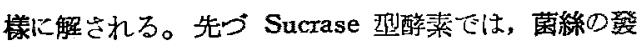
角酵素の分泌をみない5 倍澧度は別として，20倍を

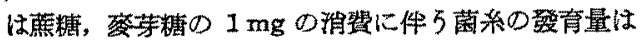
40〜160 倍及び標準液に比し極めて僅少である。同羕 に Amylase 型では 40 倍濃度が Sucrase 型の 20 倍 に相當する。一方 Sucrase 型の 10 倍, Amylase 型

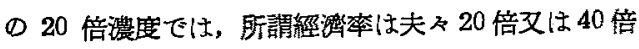

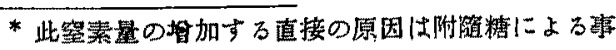
准磪めえた。

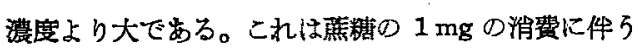
菌系而の堌加は 20 倍より方之つて多くなる事を意味

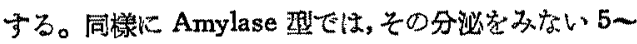
10 倍濃度は別として，20 倍では菌系雷が $1 \mathrm{mg}$ 墫加 するに要する潜粉量は 40 倍より蜜ら少量ですむ事に なる。今 Cephalothecin の影㗪下に於て秷熱病菌の

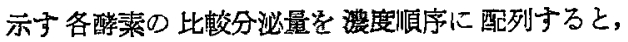
Sucrase 型飞於ては Sucrase $5<10<20>40 \sim 160$. 䅺準, Maltase は 5〜10<20>40〜160・禋準であり， Amylase 型では 5〜10<20<40>80〜160・標準とな る。即醉素の比較分泌量の最大值 (經洹率の最小值) を示するの, Sucrase - Amylase 兩䍿とも5〜10倍 の高濃度になく，20 倍或は40 倍の中間濃度にする。

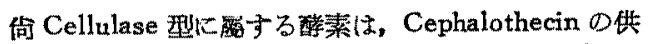

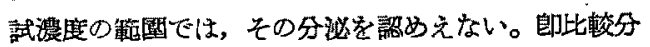
泌量は 5〜160<標準で示される。

他方 Cephalothecin : た莚理した稻苗は，稻熱病に 對する抵抗性穕得度が處理㳖度と必ずしる平行的でな く,20 倍濃底で最高度に發揮されるが5〜10 倍では

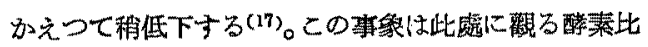
垔分泌量が濃度に件つて變化する樣相とよく一政して

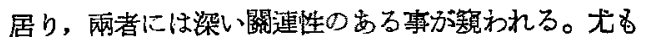
Cephlothecin 5 倍濃度ては程熱病菌の發育が極度に 抑制され酵素の分泌を認めえたので，該濃度に上る處

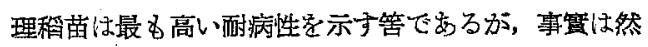
らずして前記の簿り 10 婄よりも更に发つた抵抗性を

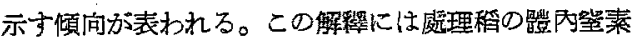

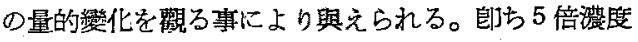

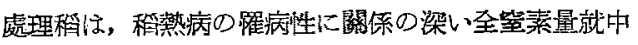

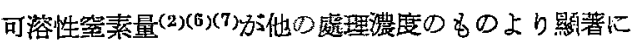
霓加する事*を認めえた (20) 倍に此し稍抵揬性が劣る原因之考えられる。

以上要するに稻苗が Cephalothecin 虎理により稳 熱病に對し抵抗性を示しろるのは，吸收された Ce-

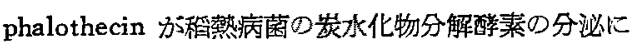

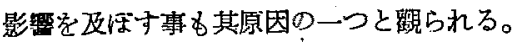

(昭和 28 年 1 月 7 日受理)

\section{引用女献}

（1）服部静夫：植物生理化學晏驗 (1941), 301 361.

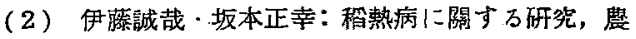
林省委託昭和 16 年度焃告, 1 40, (1942)

(3) Oppenheimer, C.: Die Fermente und ihre Wirkungen. (1936), Bd. I, 174 525.

（4）大谷武夫：實驗酵素化嶨，(1944)，273～376. 
(5) 大谷吉雄：日植病壀，16 (1)：46 (1952)

(6) : 日植病䧼, 16 (1)：46 (1952)

(7) - : 日植病冁, $16(3,4): 97 \sim 102(1952)$

(8).———日植病耀, $16(3,4): 176(1952)$

（9）坂村 徹：植物生理學（1943） 210 289.

(10) 田中正三・香月裕堂：日植病報，15(3,4): 109 〜113 (1951)

(11) - 辻二即!：日植病啹, 16(1): 31 (1952)

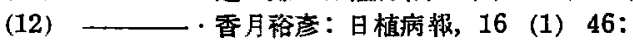
(1952)
(13) Tochinai, Y.and Nakano, T.: Jour. Fac Agr. Hokkaido Imp. Univ. 44(4): 183 229(1940)

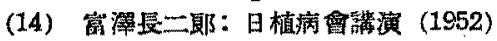

(15) 吉井 辟: 日植病数, $13(3,4): 37 \sim 40$ (1949)

(16) ——: : 日植病教, $14(3,4): 84 \sim 88$ (1950)

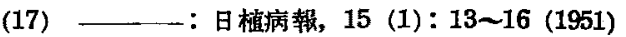

(18) ㄷ..：日植病叝, 15 (2)：82～83 (1951)

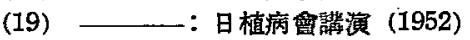

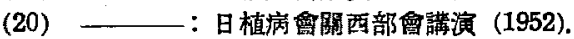

\section{Résumè}

In order to research the influence of cephalothecin upon the secretion of some carbohydrases by the blast fungus, Piricularia oryzae CAv.. cultural experiments were carried out using Tochinai and Nakano's synthetic nutrient solution, with addition of Biotin $(15-20 \mathrm{mr} / 1 \mathrm{cc}$.) and vitamin $B_{1}(15 \sim 20 r / 1$ cc. $)$.

In the solutions. cephalothecin was added at strengths of 1:5 160. Half of the lots was provided with one of the carbohydrates, including sucrose. maltose, soluble starch and cellulose and another half lacked. After 10 -days culture at $25^{\circ} \mathrm{C}$, determinations of reducing sugars were made upon the cultured solutions.

When the fungus was cultured in cephalothecin solutions with carbohydates, there were increase in dry weight of mycelial mat, and decrease in weight of non-reducing sugars, as against the solutions without any carbohydrate. The differences are shown as $M$ and $S$ respectively. The ratio $S$ : $M$ is temporarily called as the relative secretion value.

When sucrose is supplied as the carbon source, the ratio $S: M$ is highest at the concentration of 1:20 cephalothecin (cf. table 5). Such secretions as of sucrase by the fungus may be called suc- rase-type. Maltase also belongs to this type.

In the solution containing soluble starch, the value is maximum at the concentration of $1: 40$ cephalothecin. These phases, which are quite different from those in sucrase-type, may be named amylase-type.

No cellulose was utilized by the fungus in the presence of cephalothecin. This, together with other carbohydrates-emulsin, inulinase, lactase, mannase, pectinase and xylanase-may be included in cellulase-type.

The relative secretion value $(S: M)$ shows the amount of the carbohydrate consumed by the fungus to increase $1 \mathrm{mg}$. of the mycelium in dry weight. Accordingly, for the consumption of 1 mg. of sucrose or soluble starch, the increase in dry weight of mycelium is to be far less in $1: 20$ or $1: 40$ solution of cephalothecin than either in 1: 80 160 or in the check solution. In 1:5 10 solutions, the growth of the fungus is extremely poor. Thus, the phases of $S: M$ suggests certain connection between the fungus's secretion of carbohydrases under the influence of cephalothecin and the resistance to blast disease of the rice plant treated with cephalothecin.

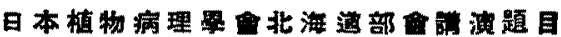

(3)

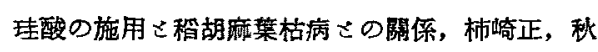
野勇治 (山形農試庄內分場)

稻苗病菌の時期的消長について．鐙谷大節， 池田正幸 (東北農陚)

稳苗席敗病に關する 2,3 の試驗，阿部忠三郎，

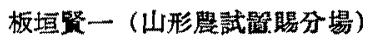

稻苗度敗病に關する研究第3 報 病原微生物飞 接種溫度との開係．永井政治，高橋喜夫，传藤 克 已(岩手大學)

稻小粒菌核病並びに紋枯病に對する新殺菌劑の防

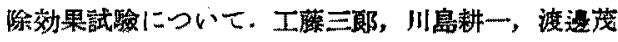

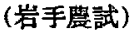

昭和 27 年度庄內地方に於け万稻病の多登生を

2,3 の觀察，柿崎正 (山形整試庄肉分場)

小麥赤銹病の春季發生源に舅す万調查, 渡遗茂, 川島耕一（湈手崖試）

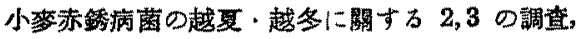

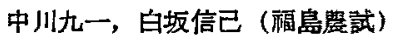

4 月下旬乃至 5 月上旬に於け万發生程度及び氣象 要素による秋播小麦赤銹病發生漯察法について。成 田武四，真野豐（道立農試） 